\title{
KOMPETENSI KEILMUAN DAN BIDANG PEKERJAAN ALUMNI PERGURUAN TINGGI (Studi Pada Profil Alumni Jurusan KPI Fakultas Dakwah Dan IImu Komunikasi)
}

\author{
Masran
}

\begin{abstract}
Abstrak
Profil Alumni suatu pendidikan tinggi terlihat dari kiprah dan kinerjanya di masyarakat. Jurusan/Program studi yang dipilih mahasiswa memiliki relevansi yang sangat penting dengan bidang pekerjaan yang akan dijalaninya setelah lulus menjadi alumni. Demikian pula dengan alumni Jurusan KPI Fakultas Dakwah dan IImu Komunikasi UIN Syarif Hidayatullah Jakarta Tahun Lulus 2007 - 2010. Bagaimana bidang pekerjaan dan kiprah mereka setelah lulus? Apakah bidang pekerjaan mereka relevan dengan kompetensi keilmuan yang dimilikinya atau tidak? Itulah yang akan dicari jawabannya melalui tulisan ini. Sebagai sebuah hasil penelitian, tulisan ini membandingkan profil alumni pada dua periode kelulusan, lulusan tahun 2002 - 2006 dan lulusan tahun $2007-2010$. Perbandingan ini dilakukan karena kedua periode kelulusan tersebut menerapkan kurikulum yang berbeda, yaitu Kurikulum Berbasis Isi (KBI) untuk periode pertama dan

Kurikulum Berbasis Kompetensi (KBK) untuk periode yang kedua. Dari hasil perbandingan ini diperoleh kesimpulan, bahwa sebagian besar alumni jurusan KPI lulusan tahun 2007 - 2010 memiliki pekerjaan utama pada bidang administrasi umum dan sebagian besar juga tidak memiliki pekerjaan tambahan. Dibandingkan dengan hasil penelitian sebelumnya, pada pekerjaan utama telah terjadi peningkatan persentase alumni yang bekerja pada bidang admnistrasi umum dan penurunan persentase yang bekerja pada bidang pendidikan (mengajar). Sedangkan pada bidang pekerjaan tambahan, terjadi peningkatan persentase alumni yang tidak memiliki pekerjaan tambahan, dan penurunan persentase yang bekerja sebagai penceramah.
\end{abstract}

Kata Kunci: Profil Lulusan, Kompetensi, Kurikulum, Pekerjaan Utama, Pekerjaan Tambahan

\section{A. Pendahuluan}

Penelitian tentang profil alumni sangat diperlukan untuk memperoleh gambaran nyata tentang keberadaan alumni suatu jurusan yang hasilnya dapat digunakan sebagai database dan indikator ketercapaian tujuan jurusan/program studi dan sekaligus sebagai bahan kajian untuk melakukan review kurikulum, serta memonitor dan 
mengevaluasi kinerja civitas akademika Jurusan KPI Fakultas Dakwah dan Komunikasi.

Data alumni tersebut merupakan data yang penting untuk segera dimiliki oleh jurusan, mengingat berbagai aktivitas administrasi yang syarat dengan ketersediaan data seperti untuk keperluan akreditasi jurusan, pengembangan kurikulum dan lain-lainnya. Bertitik tolak dari kepentingan-kepentingan inilah, maka penelitian ini dilakukan guna memperoleh kelengkapan informasi tentang profil alumni jurusan KPI Fakultas Dakwah dan IImu Komunikasi.

Selain itu, penelitian ini menjadi lebih penting lagi, karena alumni yang lulus mulai tahun 2007 ini adalah mereka yang mulai mengikuti perkuliahan sejak tahun akademik 2003/2004, saat dimulainya pemberlakuan Kurikulum Berbasis Kompetensi (KBK). Sehingga dari hasil penelitian ini diharapkan akan diperoleh perbandingan tentang profil lapangan kerja yang mereka jalani, antara produk Kurikulum Berbasis Isi (KBI) dengan KBK. Perbedaan substansi antara kedua periode kurikulum ini terlihat sangat signifikan pada jurusan KPI, terutama pada aspek muatan IImu Dakwah dan IImu Komunikasi. Pada KBI lebih kaya dengan muatan-muatan IImu Dakwah, sedangkan pada KBK lebih mengedepankan IImu-ilmu Komunikasi.
Dengan demikian, jika proses pembelajaran berjalan secara konsisten, maka akan melahirkan profil alumni yang berbeda pula sebagai konsekwensi logis dari produk dua model kurikulum yang berbeda.

Dari latar belakang masalah di atas, kami membatasi subjek penelitian ini hanya pada alumni jurusan KPI tahun lulus 2007 sampai tahun 2010 dengan asumsi bahwa alumni tahun 2011 - 2012 diperkirakan belum berperan atau berkiprah banyak, setidak-tidaknya masih belum stabil atau masih dalam proses pencarian status, karena status kesarjanaan mereka masih berusia sekitar satu tahun.

Selain dari itu, mereka yang lulus antara tahun 2007 - 2010 sebagian besar (lebih dari 90\%) adalah mahasiswa yang masuk (mendaftarkan diri) sebagai mahasiswa antara tahun 2003 - 2006 . Hal ini berarti, bahwa mereka mengikuti satu sistem kurikulum, yaitu Kurikulum Berbasis Kompetensi (Competency Based Curriculumm) yang mulai diberlakukan di UIN Syarif Hidayatullah Jakarta, khususnya pada Jurusan KPI mulai tahun 2003. Sedangkan mahasiswa angkatan sebelumnya mengikuti kurikulum berbasis isi (Content Based Curriculumm) yang diberlakukan pada Jurusan KPI sampai dengan tahun 2002. 
Masalah yang hendak dicari jawabannya dalam penelitian ini adalah bagaimana keberadaan alumni jurusan KPI Fakultas Dakwah dan komunikasi di tengah masyarakat ditinjau dari kiprah alumni, siapa dan mengerjakan apa yang dirinci sebagai berikut:

1. Apa aktivitas utama alumni jurusan KPI tahun lulus 2007-2010?

2. Apa aktivitas lain alumni jurusan KPI tahun lulus 2007-2010?

3. Bagaimana pandangan mereka tentang implikasi kurikulum Jurusan KPI terhadap lapangan kerja yang mereka jalani?

\section{B. Definisi Operasional}

Profil Alumni yang dimaksudkan dalam penelitan ini adalah peran atau pekerjaan yang dilakukan oleh lulusan suatu jurusan dalam kehidupannya di masyarakat. Pekerjaan/aktifita meliputi aktifitas utama dan aktifitas Tambahan. Aktivitas pokok/aktifitas utama yang dimaksud adalah tugas atau pekerjaan utama yang meliputi: Ceramah, Mengajar, Bekerja pada Media, Administrasi Kegiatan Dakwah, Administrasi Umum, melanjutkan studi, Dagang/Bisnes, serta pekerjaan lain-lain atau tidak kerja. Sedangkan yang dimaksud aktivitas tambahan adalah tugas atau pekerjaan alumni yang sifatnya sebagai sambilan atau tidak tetap (temporer) atau bersifat di luar pekerjaan pokok.

Kompetensi adalah kemampuan atau keahlian yang dimiliki seseorang sehingga berwenang untuk melakukan suatu pekerjaan.

Kurikulum yang dimaksudkan dalam penelitian ini adalah dokumen (curriculumm plan), berupa daftar mata kuliah yang diajarkan pada jurusan KPI.

Bidang pengkajian dalam penelitian ini meliputi siapa, mengerajakan apa, berpenghasilan berapa, dan adakah keterkaitan/kegunaan mata kuliah yang dipelajarinya di jurusan KPI dengan bidang pekerjaan utama yang ditekuninya. Konsep siapa, dimaksdukan untuk menjawab alumni tahun lulus berapa. Mengerjakan apa yang dimaksud untuk menjawab jenis tugas atau aktivitas pekerjaan alumni baik yang pokok maupun yang tambahan.

Dalam penelitian ini populasinya adalah seluruh alumni yang lulus ujian sarjana $\mathrm{S} 1$ dan mengikuti wisuda pada tahun 2007 sampai dengan 2010 sebanyak 579 orang. Penelitian ini dilakukan di seluruh wilayah Indonesia, tempat para alumni tersebut berdomisili.

Semula penelitian ini akan dilakukan dengan pendekatan survey terhadap seluruh unit populasi, namun karena keterbatasan daya jangkau, 
biaya, tenaga dan waktu, maka tidak semua unit populasi dapat dijadikan sumber data. Walaupun demikian, seluruh unit populasi memperoleh kesempatan yang sama untuk menjadi responden. Hal ini dilakukan dengan mengirimkan angket, sebagai alat pengumpul data, ke semua unit populasi; tapi tidak semua angket tersebut dikembalikan. Hanya sekitar $20 \%$ angket tersebut terisi dan dikembalikan. Sungguhpun demikian, penelitian ini tetap berpegang pada prinsip total sampling yang memiliki tingkat keterpercayaan yang tinggi karena telah memberikan peluang yang sama kepada setiap satuan elementer untuk menjadi responden.

Selain itu, derajat keterpercayaan sampel yang diambil dalam penelitian ini juga terlihat dari sebaran sampel yang terambil dari kerangka sampling meliputi perwakilan dari seluruh tahun lulusan, bahkan juga keseimbangan jumlah responden dari segi jenis kelaminnya.

Besaran sampel jenis kelamin lakilaki sebesar 20,99 \% dari jumlah laki-laki pada populasi. Demikian pula besarnya sampel jenis kelamin perempuan sebesar $19.79 \%$ dari jumlah populasi berjenis kelamin perempuan. Dari kedekatan angka prosentase sampel dari segi jenis kelaminnya menunjukkan bahwa teknik sampling ini merupakan teknik proportional quota sampling dari karakteristik jenis kelamin. Karena dalam quota sampling, menurut Sanapiah Faisal (2001: 69), penekanannya terletak pada pemberian jatah ke beberapa karakteristik populasi. Demikian pula jika dilihat prosentase sampel dari segi tahun lulus, maka kedekatan angka prosentase, terutama lulusan tahun 2008 dan 2009, juga menunjukkan teknik proportional quota sampling yang hampir sempurna. Dengan demikian dapat disimpulkan, walaupun tidak secara sistematis direncanakan penggunaan teknik quota sampling, namun dalam pelaksanaannya dapat dianggap sebagai sampel yang cukup representatif untuk menggeneralisir hasil penelitian ini kepada seluruh alumni jurusan KPI yang lulus pada tahun 2007 sampai 2010.

Teknik pengumpulan data dalam penelitian ini dilakukan melalui komunikasi langsung dan komunikasi tidak langsung. Sedangkan alat yang digunakan adalah angket yang digunakan untuk mengumpulkan data primer yaitu data yang berasal dari informasi alumni sendiri.

Teknik komunikasi langsung yang dimaksud adalah dilakukannya wawancara via telephone untuk mengisi angket yang tersedia. Teknik ini merupakan teknik yang paling efektif untuk memperoleh data dari responden sebagai sumber utamanya. Karena pada 
saat wawancara peneliti sebagai pengumpul data dapat memperjelas kalimat-kalimat yang kurang dapat dipahami oleh responden. Hanya saja teknik ini dirasakan kurang efisien, karena banyak memakan biaya (pulsa telephone), serta tidak akuratnya data sebagian besar nomor telephone wisudawan yang tercantum pada Buku Album Wisuda.

Instrumen/alat pengumpulan data yang dipakai adalah menggunakan angket dan pedoman wawancara. Angket dibuat dalam bentuk pertanyaan terbuka dan semi terbuka. Menurut Singarimbun (1989: 178) pertanyaan model ini jawabannya sudah tersusun, tetapi masih ada kemungkinan tambahan jawaban. Kelebihan pertanyaan demikian dapat membuat responden dengan leluasa mengungkapkan data keberadaan diri mereka yang sebenarnya, sesuai dengan obyek penelitian.

Pengumpulan data dilakukan dengan tiga cara, pertama bagi alumni yang nomor kontaknya masih aktif diwawancarai melalui telepon, dan kedua bagi alumni yang nomor kontaknya sudah tidak aktif kami kirimkan daftar isian/angket melalui pos atau bertemu langsung, ketiga bagi alumni yang dapat memberikan alamat email, daftar isian dikirimkan melalui email.
Untuk mengetahui tentang keberadaan alumni Jurusan KPI, kami menggunakan buku Album Wisuda sebagai dokumen pokok untuk mencari dan menemukan data nama dan alamat alumni. Selain buku tersebut peneliti juga menggunakan dokumen arsip catatan Biodata Mahasiswa yang terdapat di fakultas. Selain dari kedua macam dokumen tersebut kami juga menggunakan media internet melalui jejaring sosial Facebook dengan menelusuri alumni yang tergabung dalam group alumni Jurusan KPI.

Sebelum dianalisis, data yang terkumpul dari lapangan kami verifikasi terlebih dahulu melalui proses kerja sebagaiberikut:

a. Editing, yaitu memeriksa jawabanjawaban responden yang masih dalam bentuk jawaban terbuka untuk diteliti, ditelaah, dan dikategorisasikan pengelompokannya ke dalam variabelvariabel yang meliputi: jenis kelamin, tahun lulus, masa tunggu sebelum mendapat pekerjaan, jenis pekerjaan utama, mata kuliah yang aplikatif dan besarnya penghasilan perbulan.

b. Tabulating, yaitu menstabulasikan atau memindahkan jawaban-jawaban responden ke dalam tabel yang diolah dengan menggunakan program Microsoft Office Excel untuk mempermudah penghitungan dan 
membuat prosentasenya. Dari proses ini terbentuklah tabel-tabel frekuensi yang menjadi bahan dasar dalam proses berikutnya, yaitu analisis data.

Setelah diedit dan ditabulasikan, baru kemudian dilakukan analisis. Data dalam bentuk tabel, baik tabel tunggal maupun tabel silang, ditafsirkan dan dianalisis secara deskriptif komparatif untuk mengetahui kecenderungan masing-masing alumni dilihat dari berbagai variabel yang terkait untuk melihat hubungan diantara variabelvariabel tersebut.

\section{Profil Jurusan KPI}

Jurusan Komunikasi dan Penyiaran Islam (KPI) merupakan salah satu jurusan yang ada di lingkungan Fakultas Dakwah dan IImu Komunikasi. Bahkan ia merupakan jurusan yang pertama kali didirikan seiring dengan berdirinya Fakultas Dakwah dan IImu Komunikasi UIN Syarif Hidayatullah Jakarta. Pada waktu itu, tahun akademik 1990/1991 didirikan Fakultas Dakwah, sebagai pengembangan dari Jurusan Dakwah yang berada di bawah naungan Fakultas Ushuluddin. Jurusan pertama yang diselenggarakan adalah jurusan Penyiaran dan Penerangan Agama (PPA). Pada tahun akademik 1996/1997 jurusan ini berganti nama menjadi
Jurusan Komunikasi dan Penyiaran Islam, seperti yang ada sekarang ini.

Adapun jurusan dan program studi adalah dua nomenklatur yang dipakai secara bergantian dan kadangkala memiliki kesamaan makna dalam pemakaiannya di Fakultas Dakwah dan Ilmu Komunikasi. Namun secara teknis keseharian, kata jurusan lebih familiar di lingkungan civitas akademika Fakultas Dakwah dan IImu Komunikasi. Sedangkan kata prodi lebih sering digunakan dalam hubungan administratif dengan lembaga-lembaga lain di luar UIN Syarif Hidayatullah Jakarta, seperti dengan BAN-PT, Kemenag, dan lainlainnya. Selain sebutan jurusan dan program studi (prodi), di lingkungan Fakultas Dakwah dan IImu Komunikasi juga terdapat istilah konsentrasi yang diartikan sebagai pengembangan dari jurusan sebelum menjadi program studi. Sebuah konsentrasi akan berubah menjadi program studi apabila sudah mendapatkan legalitas dari Kemenag dan atau Kemendikbud.

Jurusan/program studi/konsentrasi yang ada di Fakultas Dakwah dan IImu Komunikasi saat ini meliputi program studi Komunikasi dan Penyiaran Islam (KPI), Konsentrasi Jurnalistik, Program Studi Bimbingan Penyuluhan Islam (BPI), Program Studi Manajemen Dakwah (MD), Program Studi Pengembangan 
Masyarakat Islam (PMI), dan Program Studi Kesejahteraan Sosial (Kessos)

Dalam perjalanan sejarahnya Jurusan KPI mengalami beberapa kali perubahan nama. Selain dari pergantian nama jurusan, nama Fakultas pun mengalami perubahan dari Fakultas Dakwah IAIN Syarif Hidayatullah Jakarta menjadi Fakultas Dakwah dan Komunikasi UIN Syarif Hidayatullah Jakarta. Perubahan nama fakultas ini seiring dengan perubahan kelembagaan IAIN menjadi UIN yang dikukuhkan dengan Keputusan Presiden RI No. 31 Tahun 2002. Perubahan status kelembagaan Institut menjadi Universitas juga berimplikasi pada penambahan dan perubahan arah pengembangan disiplin ilmu sesuai dengan tuntutan zaman. Jika pada tahun-tahun sebelumnya fakultas memfokuskan diri pada pengembangan IImu Dakwah dan berbagai disiplin ilmu pendukungnya, maka sejak terjadinya alih status IAIN menjadi UIN, Fakultas Dakwah juga menambah dan mengembangkan disiplin IImu Komunikasi.

Sebagai jurusan tertua, dengan sandangan nama kata Komunikasi, Jurusan Komunikasi dan Penyiaran Islam merupakan jurusan terdepan dalam pengembangan disiplin IImu Komunikasi. Karena itu, sejak tahun akademik 2003/2004 terjadi perubahan kurikulum ke arah penambahan muatan disiplin ilmu komunikasi yang lebih banyak pada Jurusan KPI.

Dalam perkembangan selanjutnya, pada tahun akademik 2004/2005, jurusan KPI membuka konsentrasi Jurnalistik, sebagai wadah untuk menampung minat mahasiswa yang secara spesifik ingin fokus pada salah satu bidang IImu Komunikasi. Konsentrasi ini diharapkan terus tumbuh sebagai cikal-bakal berdirinya Program Studi Jurnalistik. Namun karena berbagai macam hambatan, hingga saat ini konsentrasi ini belum menjelma menjadi Program Studi atau Jurusan. Sungguhpun demikian, keberadaan konsentrasi ini tetap dikelola oleh suatu sub sistem tersendiri walaupun masih tetap berada di bawah naungan Jurusan KPI.

Fakultas Dakwah dan Komunikasi UIN Syarif Hidayatullah Jakarta dalam merekrut mahasiswa menerima mahasiswa dari kalangan yang heterogen. Mereka berasal dari berbagai etnis dan suku yang ada di Indonesia. Seperti dari Aceh, Padang, Medan, Palembang, dan daerah-daerah lain di kepulauan Sumatera. Demikian pula dari wilayah-wilayah Indonesia bagian Tengah dan Timur; bahkan dari negara-negara tetangga, seperti Malaysia, Singapore, Brunai Darussalam, Thailand, dan lainlain. Namun daerah asal mahasiswa yang 
paling banyak adalah dari tempat-tempat yang tidak terlalu jauh dengan wilayah Ciputat, tempat berdirinya kampus UIN Syarif Hidayatullah Jakarta. Seperti Jakarta, Bogor, Tangerang Depok dan Bekasi (Jabodetabek) dan daerah sekitarnya.

Perkembangan jumlah mahasiswa baru dari tahun ke tahun semakin meningkat. Hal ini merupakan indikasi, bahwa jurusan KPI dari tahun ke tahun semakin diminati oleh masyarakat. Lebihlebih di era informasi seperti sekarang ini. Oleh sebab itu, merupakan tantangan yang besar bagi pengelola lembaga ini untuk terus melakukan pembenahan dalam berbagai bidang, serta meningkatkan pelayanan ke arah yang lebih baik, sehingga pada gilirannya jurusan ini akan menjadi mascot, tidak hanya bagi Fakultas Dakwah dan IImu Komunikasi, tapi juga bagi UIN Syarif Hidayatullah Jakarta.

Mahasiswa jurusan KPI yang berasal dari berbagai daerah ini datang ke kampus UIN Syarif Hidayatullah Jakarta untuk mengikuti kuliah di Fakultas Dakwah. Selama kuliah mereka menetap di berbagai tempat, sesuai dengan keberadaan mereka masing-masing. Keberadaan mereka yang dimaksudkan dalam hal ini adalah kondisi yang melatar belakangi mereka untuk memilih tempat tinggal selama kuliah. Bagi mahasiswa yang berasal dari wilayah yang tidak jauh dari kampus, seperti wilayah Jabodetabek dan sekitarnya, pada umumnya mereka tetap bertempat tinggal di rumah asalnya masing-masing, dan biasanya mereka pergi dan pulang setiap hari ke kampus. Sedangkan bagi mereka yang berasal dari daerah yang jauh dari kampus, namun memiliki keluarga yang bertempat tinggal di dekat kampus, maka pilihan alternatifnya adalah tinggal bersama keluarga atau menyewa rumah kontrak, kost, atau tinggal di asrama.

Berbeda halnya dengan mahasiswa yang berasal dari luar wilayah Jabodetabek, lebih-lebih yang berasal dari luar negeri dan tidak memiliki keluarga di sekitar Jakarta. Pada umumnya mereka yang disebutkan terakhir ini memilih untuk bertempat tinggal di sekitar kampus dengan cara mengontrak rumah untuk ditempati bersama-sama dengan mahasiswa lain, baik mahasiswa yang berasal dari jurusan atau fakultas yang sama, maupun dengan mahasiswa lain; bahkan tidak jarang yang tinggal bersama dengan mahasiswa dari perguruan tinggi lain.

Mahasiswa jurusan KPI yang berdomisili di wilayah sekitar kampus merasakan adanya suasana kuliah yang lebih kondusif dan lebih efektif untuk mengikuti kuliah, melaksanakan tugastugas perkuliahan dan mengikuti 
kegiatan-kegiatan ekstra kulikuler. Hal ini terjadi karena hampir setiap saat mereka dapat berinteraksi dengan sesama mahasiswa dan berdiskusi tentang masalah-masalah akademis yang dihadapinya, sehingga lebih banyak menyerap informasi akademis daripada teman-temannya yang tinggal jauh dari kampus. Oleh sebab itu, sebagian mahasiswa yang berasal dari wilayah Jabodetabek pun berusaha untuk berdomisili di sekitar kampus.

Keberadaan mahasiswa di lingkungan kampus, serta aktifitasnya di luar kepentingan perkuliahan, seringkali ikut mewarnai prospek kehidupannya setelah menyelesaikan studi. Pada umumnya mahasiswa jurusan KPI, setelah menyelesaikan studi di kampus UIN Jakarta mereka kembali ke daerah asalnya masing-masing. Hal inilah yang sebenarnya diharapkan oleh kebanyakan orang tua dan masyarakat di daerah asal mereka. Sikap demikian juga sejalan dengan missi dakwah yang terdapat dalam Alquran (Q.S. At-Taubah/9: 122). Selain dari pulang kampung, ada juga di antara mahasiswa yang sudah menyelesaikan studinya yang memilih untuk tetap tinggal di Jakarta dan sekitarnya dengan alasan dan kepentingan yang berbeda-beda. $\mathrm{Di}$ antara alasan-alasan yang sering mereka kemukakan untuk tetap tinggal di Jakarta pada umumnya adalah karena di Jakarta sudah menemukan lapangan kerja yang menjanjikan, sementara di daerah asalnya masih belum bisa diharapkan. Selain dari alasan lapangan kerja, keberadaan sebagian alumni menetap di Jakarta adalah karena ingin melanjutkan study ke program pascasarjana, baik program pascasarjana yang ada di lingkungan UIN Syarif Hidayatullah Jakarta, maupun di perguruan tinggi negeri lain atau swasta yang ada di Jakarta.

Sebagaimana disebutkan sebelumnya, bahwa jumlah responden pada penelitian ini sebanyak 118 orang alumni. Jumlah inilah yang dikumpulkan datanya dan akan dideskripsikan pada bagian ini sesuai dengan tujuan penelitian. Sebagai gambaran awal tentang keberadaan responden ini akan dilihat dari segi angkatan/tahun masuk dan tahun lulusnya. Hal ini dipandang perlu untuk melihat seberapa besar jumlah responden yang masuk pada tahun akademik sebelum 2003/2004 dan sesudahnya. Karena pada tahun akademik inilah mulai diberlakukannya Kurikulum Berbasis Kompetensi (KBK) pada Jurusan KPI. 


\section{Aktifitas Utama Alumni Jurusan KPI}

Secara teoritis, kurikulum yang disajikan oleh suatu jurusan akan berimplikasi pada kompetensi yang dimiliki oleh alumninya, dan pada gilirannya juga akan menentukan lapangan kerja yang mereka jalani. Lapangan kerja apa yang dijalani oleh alumni merupakan gambaran dari keberadaan profil alumni itu sendiri. Dengan demikian kurikulum - khususnya Curriculum Plan dalam bentuk daftar mata kuliah yang ditawarkan, merupakan breakdown dari kompetensi lulusan yang sudah ditetapkan oleh Jurusan dan tergambar dalam kategorisasi Kompetensi Utama, Kompetensi Pendukung dan Kompetensi Lainnya. Kompetensi lulusan, menurut tim penyusun Pedoman Pengembangan KBK Kemendikbud (Dirjen Dikti: 2008, 26), selayaknya dirumuskan setelah menetapkan profil alumni terlebih dahulu. Karena itu, profil alumni merupakan salah satu tolok ukur keberhasilan penyelenggaraan kurikulum pada suatu Program Studi.

Alumni Jurusan KPI dalam menjalankan kiprahnya sebagai sarjana Strata 1 (satu) yang memiliki kompetensi di bidang Komunikasi dan Penyiaran Islam diharapkan dapat melakoni profesi sesuai dengan kompetensi bidang ilmu yang dimilikinya.

$$
\text { Pekerjaan pada bidang }
$$

administrasi umum, jika dikaitkan dengan bidang ilmu yang dibutuhkan, sebenarnya lebih mendekati pada rumpun IImu Manajemen dan Ilmu Administrasi. Namun karena kedua bidang ilmu ini tidak ditawarkan pada kurikulum Jurusan KPI, maka sebagian besar alumni yang bekerja pada bidang ini berpendapat, bahwa rumpun mata kuliah yang paling berguna dalam menunjang lapangan kerja mereka adalah rumpun Mata Kuliah IImu Komunikasi.

Selain dari alumni yang bekerja pada bidang administrasi umum dan produksi media yang menganggap pentingnya IImu Komunikasi dalam bidang pekerjaannya, alumni yang bekerja sebagai pedagang pun sebagian besar (88\%) di antara mereka menganggap IImu Komunikasi sebagai IImu yang paling berguna dalam bidang pekerjaan mereka. Hanya saja bidang IImu Komunikasi yang mereka maksudkan bukanlah teori-teori IImu Komunikasi, melainkan penguasaan teknologi informasi dan komunikasi yang lebih luas dan mendalam. Seperti pengetahuan-pengetahuan teknis pengoperasian komputer, penguasaan media internet, dan lain-lainnya. 
Persentase terbesar kedua, yaitu sebanyak 32 orang responden $(27,12 \%)$, pekerjaan alumni adalah sebagai tenaga pengajar (guru). Kategorisasi guru dalam hal ini meliputi guru agama di sekolahsekolah umum maupun sekolah agama, guru private less yang datang ke rumahrumah, termasuk juga di dalamnya trainer (pelatih) pada lembaga-lembaga pemerintahan maupun swasta. Dari 32 orang responden yang bekerja sebagai guru, 19 orang (59\%) di antaranya berpendapat bahwa IImu Komunikasi adalah IImu yang paling berguna bagi mereka dalam melaksanakan pekerjaan sebagai guru. Kedekatan profesi guru dengan Kompetensi Jurusan Komunikasi dan Penyiaran Islam terlihat pada hasil penelitian sebelumnya, yaitu penelitian tentang Profil Alumni Jurusan KPI yang lulus pada tahun 2002 - 2006. Bahkan pada hasil penelitian terdahulu, persentase alumni yang bekerja sebagai guru menempati posisi teratas. Hal ini berbeda dengan hasil penelitian saat ini terhadap alumni yang lulus pada tahun $2007-2010$.

Alumni Jurusan KPI yang lulus pada tahun 2002 - 2006 persentase terbesar $(42,86 \%)$ bekerja sebagai guru; sedangkan alumni lulusan tahun 2007 2010 yang bekerja sebagai guru hanya $27,12 \%$, menempati persentase terbesar kedua setelah alumni yang bekerja pada bidang administrasi umum. Hal ini berarti terjadi penurunan persentase alumni yang bekerja sebagai guru sebesar 15,74\%; dan peningkatan persentase alumni yang bekerja pada bidang administrasi umum sebesar $14,43 \%$.

Penurunan dan peningkatan persentase pada kedua bidang pekerjaan ini tidak terlepas dari perbedaan kurikulum yang diterapkan pada kedua periode lulusan tersebut. Kurikulum yang diterapkan pada periode pertama (lulusan tahun 2002 - 2006) lebih banyak mendorong alumninya untuk bekerja sebagai guru; sementara kurikulum yang diterapkan pada periode kedua (Iulusan tahun 2007 - 2010) lebih cendrung membawa alumninya pada bidang pekerjaan administrasi umum.

Perbedaan yang sangat menonjol dalam formulasi kedua periode kurikulum tersebut terletak pada porsi penawaran rumpun mata kuliah IImu Dakwah dan rumpun mata kuliah IImu Komunikasi. Pada kurikulum terdahulu (yang diikuti oleh alumni lulusan tahun 2002 - 2006) adalah kurikulum yang diberlakukan untuk angkatan tahun 1999 - 2002; sedangkan kurikulum berikutnya adalah kurikulum yang diberlakukan mulai tahun 2003 sampai 2006, bahkan sampai sekarang.

Pada kurikulum terdahulu porsi penawaran antara rumpun mata kuliah IImu Komunikasi dengan IImu Dakwah 
hampir seimbang jumlah sksnya. Sedangkan pada kurikulum periode berikutnya jumlah sks rumpun mata kuliah IImu Komunikasi jauh lebih besar dari jumlah sks rumpun mata kuliah IImu Dakwah.

Jika dihubungkan dengan tabel yang membandingkan pekerjaan utama alumni dapat disimpulkan, bahwa berkurangnya porsi sks rumpun mata kuliah IImu Dakwah berimplikasi terhadap berkurangnya kiprah alumni dalam bidang pekerjaan sebagai guru. Sedangkan pada rumpun mata kuliah IImu Komunikasi dapat disimpulkan, bahwa semakin besar porsi rumpun mata kuliah ini semakin besar pula persentase alumni yang bekerja pada bidang administrasi umum.

Realitas pekerjaan alumni pada dua bidang yang memiliki persentase tertinggi pertama (bidang administrasi umum) dan tertinggi kedua (pendidik/guru) sebenarnya tidak mencerminkan secara utuh kompetensi hasil belajar Jurusan/prodi KPI yang dituangkan dalam Buku Panduan Akademik Fakultas Dakwah dan Komunikasi UIN Syarif Hidayatullah Jakarta Tahun 2004/2005. Dalam buku ini ditegaskan bahwa kompetensi lulusan jurusan KPI antara lain meliputi:

a. Memahami secara terpadu wawasan keilmuan di bidang Komunikasi dan Penyiaran Islam. ... b. Menjadi praktisi dan ahli di bidang Komunikasi dan Penyiaran Islam yang profesional. Indikator profesional dalam hal ini ditandai dengan kriteria:

1) Efektif dan efisien dalam menjalankan tugasnya

2) Menekuni dan mencintai pekerjaannya

c. Menjadi praktisi dan ahli di bidang Komunikasi dan Penyiaran Islam yang responsif dan proaktif

d. Menjadi praktisi dan ahli di bidang Komunikasi dan Penyiaran Islam yang kreatif dan inovatif

e. Komunikatif dan demokratis

f. Menjadi praktisi dan ahli di bidang Komunikasi dan Penyiaran Islam yang mencintai ilmu pengetahuan.

Sebagai praktisi dan ahli di bidang Komunikasi, jika diimplementasikan dalam dunia kerja maka akan menghasilkan alumni yang bekerja pada bidang-bidang:

1) Komunikasi Massa sebagai: produser acara, programmer, reporter, Script Writer, manager produksi media, dan lain-lainnya.

2) Public Relation: Lobbying, Manajer Event, Manajer Kampanye,

3) Business Communication Marketing: Negosiator, Advertising, Perencana Periklanan, dan lainlainnya. 
4) Konsultan Komunikasi,

5) Analis Media,

6) Event Organizer,

7) Akademisi: Peneliti,

Dosen/Pengajar pada bidang IImu Komunikasi.

Para alumni yang dikategorikan bekerja pada lembaga produksi media yang membutuhkan bidang keahlian IImu Komunikasi, sebagaimana terlihat pada tabel 1 di atas menempati persentase terbesar ketiga, yaitu 16,95\% (20 dari 118 responden). Posisi mereka dalam bidang pekerjaan ini meliputi: Penyiar radio, staf administrasi pada lembaga penyiaran, script writer, manager produksi, bagian humas di instansi perkantoran, dan lainlainnya. Persentase alumni yang bekerja pada bidang ini, jika dibandingkan dengan hasil penelitian terdahulu terlihat mengalami peningkatan, walaupn hanya $6,47 \%$. Peningkatan persentase ini sejalan dengan penambahan porsi rumpun mata kuliah IImu Komunkasi. Hanya saja jika dihubungkan dengan besarnya porsi rumpun mata kuliah IImu Komunikasi yang ditawarkan sebagai mata kuliah kompetensi utama, peningkatan angka prosentase ini dirasakan masih belum memadai.

Urutan persentase terbesar keempat adalah alumni yang bekerja sebagai pedagang, yaitu sebesar $6,78 \%$ (8 dari 118 orang). Profesi kerja bidang ini memang tidak secara tegas menjadi ekspektasi kompetensi alumni, namun dalam kelompok mata kuliah kompetensi lain-lain terdapat penawaran mata kuliah Kewirausahaan. Akan tetapi hal ini tidak menjadi patokan, bahwa mereka menjadi pedagang karena adanya mata kuliah ini.

Urutan persentase berikutnya adalah alumni yang bekerja pada bidang kerja lain-lain. Bidang kerja ini antara lain meliputi tugas sebagai asisten pribadi pejabat, penghias/tata boga, caleg legislatif, dan LSM. Pekerjaan bidang ini memang tidak mencerminkan kompetensi manapun dari kompetensi keilmuan jurusan, akan tetapi tidak berarti bahwa kurikulum yang mereka ikuti dalam perkuliahan tidak berguna bagi kehidupan mereka.

Persentase terkecil adalah pekerjaan sebagai penceramah, yaitu hanya $0,85 \%$ ( 1 dari 118 orang). Padahal bidang pekerjaan ini merupakan salah satu cerminan kompetensi jurusan KPI, yaitu ahli dan trampil dalam bidang Penyiaran Islam. Kompetensi alumni pada bidang penyiaran Islam ini dapat diwujudkan dalam pekerjaan sebagai penceramah, penyuluh agama, penulis buku-buku dan artikel tentang ajaran Islam, dan lain-lainnya.

Profesi sebagai penceramah merupakan salah satu profesi bidang keilmuan Dakwah. Demikian pula dengan 
profesi bidang keilmuan Dakwah lainnya, yaitu bekerja dalam bidang administrasi Dakwah. Persentase bidang pekerjaan ini menempati urutan terkecil kedua setelah penceramah, yaitu 1,69\% (2 dari 118 orang) responden. Jika kedua bidang ini disatukan, menjadi profesi dakwah, hanya akan menghasilkan angka persentase sebesar $2,54 \%$.

Kecilnya persentase profesi dakwah yang dijalani oleh alumni Jurusan KPI sebagai responden menunjukkan, bahwa wacana tentang dakwah sebagai profesi masih debatable. Padahal penggunaan nomenklatur kata "dakwah" sebagai nama bagi jurusan maupun fakultas di lingkungan UIN Syarif Hidayatullah Jakarta sudah berlangsung cukup lama. Hal ini berarti, bahwa profesi dakwah tidak selalu identik dengan ceramah dan kepengurusan administrasi pada lembaga-lembaga yang menggunakan kata dakwah.

Seperti disebutkan terdahulu, bahwa angket untuk pertanyaan ini bersifat terbuka. Artinya, alumni tidak digiring untuk memilih salah satu jawaban yang tersedia. Hal ini dimaksudkan untuk memperoleh jawaban tentang pekerjaan utama alumni yang lebih realistis dan obyektif. Namun suatu hal yang perlu mendapat perhatian dari hasil penelitian ini adalah rendahnya persentase alumni yang bekerja pada bidang dakwah dan komunikasi. Oleh sebab itu, menjadi sangat penting untuk mengetahui keterkaitan antara mata kuliah yang mereka ikuti pada jurusan KPI dengan lapangan kerja yang mereka tekuni.

Total bobot rumpun mata kuliah IImu Komunikasi sebanyak 65 sks atau $44,82 \%$ dari 145 sks yang ditawarkan. Persentase rumpun mata kuliah ini pada kurikulum tahun tahun 2003 mengalami pertambahan yang sangat signifikan bila dibandingkan dengan kurikulum KPI pada periode sebelumnya yang hanya sebesar $20 \%$ dari 150 sks yang ditawarkan. Karena itu sangatlah wajar jika sebagian besar alumni lulusan tahun 2007 - 2010 berpendapat bahwa rumpun mata kuliah yang paling berguna bagi aktifitas utama mereka adalah rumpun mata kuliah IImu Komunikasi.

Persentase terbesar kedua adalah rumpun IImu Dakwah dan rumpun IImuilmu Keislaman. Kedua rumpun mata kuliah ini masing-masing dipilih oleh enam orang responden dengan persentase sebesar $5,08 \%$ dari 118 orang responden. Jika kedua rumpun mata kuliah ini disatukan, dengan anggapan bahwa IImu Dakwah adalah bagian dari ilmu-ilmu keislaman, maka diperoleh angka persentase sekitar $10 \%$ alumni yang bidang pekerjaannya ditopang oleh ilmu-ilmu keislaman. 
Mata kuliah yang termasuk ke dalam rumpun IImu Dakwah dalam kurikulum yang berlaku bagi alumni tersebut terdiri dari:

1. Ilmu Dakwah (6 sks), dan

2. Retorika/llmu khithabah (3 sks).

Keseluruhan mata kuliah yang termasuk ke dalam rumpun IImu Dakwah ini berbobot 9 sks atau hanya 6,2\% dari 145 sks yang ditawarkan. Jika rumpun mata kuliah IImu Komunikasi dibandingkan dengan rumpun mata kuliah IImu Dakwah, maka diperoleh angka perbandingan 65:9 atau 44,82\% berbanding $6,2 \%$. Perbandingan bobot sks ini berbanding lurus dengan perbandingan jumlah responden yang memilih rumpun mata kuliah pendukung aktifitas utamanya, yaitu 91:6 atau $77,12 \%$ : 5,08\%. Bahkan pemilih IImu komunikasi mengalami peningkatan, sedangkan pemilih IImu Dakwah mengalami penurunan.

\section{Berdasarkan}

perbandingan

persentase pilihan alumni terhadap kedua rumpun mata kuliah ini, maka perlu dilakukan review kurikulum untuk mempertimbangkan pentingnya keberadaan rumpun IImu Dakwah ini pada jurusan KPI, sesuai dengan visi dan missi jurusan ini yang mengacu pada visi dan misi Fakultas Dakwah. Selain itu, unsur praktek dalam pelaksanaan kegiatan belajar-mengajar mata kuliah ini juga masih dirasakan sangat kurang. Oleh sebab itu, di samping menambah bobot sks-nya untuk peninjauan kembali kurikulum jurusan KPI pada masa yang akan datang, sangat penting diperhatikan muatan praktek pada masing-masing mata kuliah yang termasuk ke dalam rumpun IImu Dakwah ini.

Pada urutan persentase terbesar yang sama dengan rumpun mata kuliah Ilmu Dakwah adalah mata kuliah yang termasuk ke dalam rumpun Ilmu-ilmu Keislaman. Mata kuliah yang dikategorikan sebagai rumpun Keislaman dalam kurikulum yang diikuti oleh responden terdiri dari:

1. Metodologi Studi Islam (2 sks),

2. Ilmu Kalam (2 sks),

3. Ulumul Quran dan Tafsir I (3 sks),

4. Ulumul Hadits dan Hadits I (3 sks),

5. Akhlak-Tasawwuf (3 sks),

6. Fiqh/Ushul Fiqh (3 sks),

7. Ulumul Hadits dan Hadits II (3 sks),

8. Ulumul Quran dan Tafsir II (3 sks), dan

9. Filsafat Islam (2 sks).

Kesembilan mata kuliah ini jika dihitung dari segi bobot sks-nya hanya berjumlah 24 sks, yakni hanya 16,55\% dari 145 sks mata kuliah yang diikuti alumni. Keberadaan mata kuliah yang termasuk ke dalam rumpun IImu-ilmu Keislaman ini dalam kurikulum 2003 terlihat sangat minim dan tidak sesuai 
dengan tingkat kebutuhan alumni untuk menyampaikan materi dakwah dalam berkiprah di masyarakat.

Persentase terbesar keempat mata kuliah yang dipandang sangat berguna oleh alumni dalam melaksanakan aktifitas utamanya adalah Mata Kuliah Dasar Umum (MKDU), yaitu sebanyak 4 orang atau 2,75\% dari jumlah alumni. Mata kuliah yang dikelompokkan sebagai MKDU dalam konteks penelitian ini adalah:

1. Civic Education (2 sks),

2. Ilmu Alamiah Dasar (2 sks),

3. Sosiologi (3 sks),

4. Psikologi (2 sks),

5. Statistik Sosial (3 sks),

6. Logika Scientific (3 sks),

7. Metodologi Penelitian (3 sks).

8. Antropologi Agama (2 sks)

Keseluruhan mata kuliah yang dikelompokkan sebagai MKDU dalam hal ini, jika dilihat dari segi bobot sks-nya berjumlah 20 sks atau 135,79\% dari total sks yang harus diambil oleh alumni. Kondisi ini dirasakan terlalu besar jika dibandingkan dengan persentase alumni $(3,39 \%)$ yang memandang penting mata kuliah ini.

Mata kuliah lainnya yang juga dipilih oleh alumni sebagai matakuliah yang sangat berguna, namun persentasenya lebih kecil dari pilihan terhadap MKDU adalah mata kuliah
Kebahasaan yang dipilih oleh 3 orang atau $2,54 \%$. Sedangkan alumni yang berpendapat, bahwa tidak ada mata kuliah yang berguna bagi pelaksanaan pekerjaan utamanya hanya sebanayak 4 orang (3,39\%). Demikian pula alumni yang berpendapat bahwa semua mata kuliah berguna bagi pelaksanaan tugas utama mereka juga berjumlah 4 orang $(3,39 \%)$.

Dari keterangan di atas dapat disimpulkan, bahwa secara umum para alumni berpendapat, mata kuliah yang mereka ikuti dari kurikulum tersebut sangat berguna dalam melaksanakan pekerjaan utama mereka, walaupun tingkat keberguanannya berbeda-beda antara seorang alumni dengan alumni lainnya.

\section{E. Kesimpulan}

Dari deskripsi, analisis dan interpretasi data di atas dapat ditarik beberapa kesimpulan sebagai berikut:

1. Aktifitas Utama.

Dalam aktifitas utama, jenis pekerjaan yang paling dominan dilakukan oleh alumni jurusan KPI yang lulus pada tahun 2007 - 2010 adalah bidang administrasi umum. Hanya seorang di antara mereka yang menjadikan ceramah atau dakwah 
secara profesional sebagai aktifitas utamanya.

Jika dibandingkan dengan hasil penelitian terdahulu terhadap alumni yang lulus tahun 2002 - 2006, telah terjadi peningkatan persentase alumni yang bekerja di bidang administrasi umum sebesar 14,43\%. Sedangkan persentase alumni yang bekerja sebagai guru mengalami penurunan sebesar 15,74\%. Penurunan dan peningkatan persentase pada kedua bidang pekerjaan ini tidak terlepas dari perbedaan kurikulum yang diterapkan pada kedua periode lulusan tersebut.

Sedangkan mata kuliah yang dipandang paling berguna dalam melaksanakan aktifitas utama mereka adalah IImu Komunikasi. Hampir semua bidang pekerjaan utama alumni menempatkan IImu Komunikasi sebagai ilmu yang paling berguna bagi pekerjaan mereka, kecuali bidang pekerjaan studi lanjut yang menempatkan rumpun ilmu bahasa yang paling berguna.

Dari kenyataan ini dapat disimpulkan, bahwa sebagian besar alumni tidak bekerja pada bidang yang sesuai dengan kompetensi keilmuan yang dipelajarinya pada jurusan KPI. Baik kompetensi yang membentuk dirinya menjadi ahli dan trampil dalam bidang Komunikasi, maupun kompetensinya pada bidang Penyiaran Islam. Namun suatu hal yang menggembirakan, bahwa hampir seluruh alumni memiliki aktifitas utama, bahkan mendapatkan pekerjaan utamanya dalam kurun waktu kurang dari setahun.

\section{Aktifitas Tambahan}

Alumni jurusan KPI selain memiliki aktifitas utama, sebagian di antara mereka juga memiliki aktifitas tambahan yang bervariasi jenisnya. Jenis pekerjaan yang paling dominan dalam aktifitas tambahan mereka adalah berdagang, mengajar dan ceramah. Dalam hal ini, ceramah sebagai profesi yang didukung oleh latar belakang keilmuan para alumni jurusan KPI ditempatkan pada aktifitas tambahan. Dengan kata lain, ceramah hanya dijadikan sebagai pekerjaan sampingan oleh sebagian kecil $(5,08 \%)$ alumni.

Jika dibandingkan dengan hasil penelitian terdahulu, hasil penelitian ini menunjukkan peningkatan persentase alumni yang tidak memiliki pekerjaan tambahan sebesar $20,69 \%$. Selain itu juga terjadi penurunan persentase alumni dalam bidang pekerjaan ceramah sebesar $15,87 \%$. Dalam hal ini patut diduga bahwa berkurangnya persentase responden yang memiliki 
pekerjaan tambahan sebagai penceramah adalah karena berkurangnya porsi rumpun mata kuliah IImu Dakwah yang ditawarkan pada kurikulum periode terakhir ini. Saat ini porsi rumpun mata kuliah IImu Dakwah hanya sebesar 6,2\% dari seluruh mata kuliah yang ditawarkan.

\section{F. Saran-saran}

Berdasarkan kesimpulan di atas dapat disampaikan beberapa saran kepada berbagai pihak sebagai berikut:

1. Pengelola jurusan KPI dalam menyusun kurikulum hendaknya mempertimbangkan prospek lapangan kerja yang akan dijalani oleh alumni. Dengan kata lain, penyusunan kurikulum harus diawali dengan studi kelayakan yang mendasari penetapan profil alumni.

2. Untuk memberikan solusi alternatif, perlu diperbanyak penawaran mata kuliah pilihan guna memberikan kesempatan yang lebih luas kepada mahasiswa dalam mengembangkan kompetensi individualnya.

3. Pengelola jurusan perlu memfasilitasi mahasiswa magang pada lembagalembaga yang sesuai dengan kompetensi lulusan agar lebih dekat ke dunia kerja yang sebenarnya.
4. Mata kuliah yang ditawarkan hendaknya lebih diperkaya dengan muatan praktek, sehingga kebergunaan mata kuliah tersebut akan semakin dirasakan oleh para alumni ketika memasuki lapangan kerja. Pengayaan demikian dapat dilakukan dengan memperbanyak mitra kerja lembaga yang dimungkinkan bagi mahasiswa untuk magang. Bahkan, magang semestinya sudah menjadi keharusan bagi seluruh mahasiswa yang difasilitasi oleh lembaga (jurusan atau fakultas).

5. Mahasiswa jurusan KPI hendaknya dapat mengembangkan diri secara mandiri, kreatif dan inovatif, tidak semata-mata bergantung pada program kerja jurusan/fakultas.

\section{G. Daftar Pustaka}

Etzioni, Amitai. 1985. OrganisasiOrganisasi Modern. UI. Press, Jakarta

Fakultas Dakwah dan Komunikasi, Panduan Akademik Fakultas Dakwah dan Komunikasi UIN Syarif Hidayatullah Jakarta Tahun 2004/200

Faisal, Sanapiah, 2001, Format-format Penelitian Sosial, Rajawali Pers, Jakarta 
Kementerian Agama Rl., 2002. Keputusan Menteri Agama Republik Indonesia Nomor 414 Tahun 2002 Tentang Organisasi dan Tata Kerja Universitas Islam Negeri (UIN) Syarif Hidayatullah Jakarta

---------, 2003. Keputusan Menteri Agama Republik Indonesia Nomor 477 Tahun 2003 Tentang Satatuta Universitas Islam Negeri (UIN) Syarif Hidayatullah Jakarta

Kementrian Pendidikan Nasional, 2008, Buku Panduan Pengembangan Kurikulum Berbasis Kompetensi Perguruan Tinggi, Dirjen Dikti Kemendiknas

---------, 2009. Peraturan Menteri Pendidikan Nasionl No. 8 Tahun 2009

Kristianti, Mariana, 2002, Analisis Kompetensi Lulusan Perguruan Tinggi di Tempat Kerja, Tesis Magister Manajemen, UNDIP, Semarang

Muchson, Ali, dkk., Jurnal Ekonomia, Vol. 8, No. 1, April 2012

Mulyasa, Dr. E., M. Pd., 2002, Kurikulum Berbasis Kompetensi: Konsep, Karakteristik, dan Impelementasi, PT Remaja Rosdakarya, Bandung

Pusat Bahasa Depdiknas, 2001, Kamus Besar Bahasa Indonesia, Balai Pustaka, Jakarta
Rektor UIN Syarif Hidayatullah Jakarta, 2003. Keputusan Rektor Universitas Islam Negeri (UIN) Syarif Hidayatullah Jakarta Nomor 129 Tahun 2003 Tentang Uraian Tugas (Job Describtion) Universitas Islam Negeri (UIN) Syarif Hidayatullah Jakarta

Singarimbun, Masri, dkk. 1995, Metode Penelitian Survay, LP3ES, Jakarta

Soekanto, Soerjono. 1982. Sosiologi Suatu Pengantar. Rajawali Press, Jakarta

Suhardono, Edy. 1994. Teori Peran Konsep, Derivasi, dan Implikasinya. Gremedia Pustaka Pokok, Jakarta

Terry, George R., 1986. Asas-Asas Menejemen. Alumni, Bandung

UIN Jakarta. 2007, 2008, 2009,2010. Album Wisuda ke 67 - 82 UIN Syarif Hidayatullah Jakarta

http: //edukasi.kompas.com/ read /2010/ 08/ 04/ Latief, M., Perguruan Tinggi Ikut Sumbang Penganggur, dalam didownload pada tanggal 1 November 2013

http://www.pikiran-rakyat.com/, "Sarjana Mendominasi Pengangguran", didownload tanggal 1 November 2013

http://kpi-

fidikom.uinjkt.ac.id/index.php/akade mik/kurikulum 